\title{
Comparative hydraulic and anatomic properties in palm trees (Washingtonia robusta) of varying heights: implications for hydraulic limitation to increased height growth
}

\author{
Heidi J. Renninger · Nathan Phillips • \\ Donald R. Hodel
}

Received: 8 September 2008/Revised: 21 March 2009/Accepted: 30 March 2009/Published online: 29 April 2009

(C) The Author(s) 2009. This article is published with open access at Springerlink.com

\begin{abstract}
As trees grow taller, the energetic cost of moving water to the leaves becomes higher and could begin to limit carbon gain and subsequent growth. The hydraulic limitation hypothesis states that as trees grow taller, the path length and therefore frictional resistance of water flow increases, leading to stomatal closure, reduced photosynthesis and decreased height growth in tall trees. Although this hypothesis is supported by the physical laws governing water movement in trees, its validation has been complicated by the complex structure of most tree species. Therefore, this study tested the hydraulic limitation hypothesis in Washingtonia robusta (H. Wendl.), a palm that, while growing to tall heights, is still structurally simple enough to act as a model organism for testing. There were no discernable relationships between tree height and stomatal conductance, stomatal densities, guard cell lengths, leaf dry mass per unit area (LMA) or sap flux, suggesting that these key aspects of hydraulic limitation are not reduced in taller palms. Taller palms did, however, have higher maximum daily photosynthetic assimilation rates, lower minimum leaf water potentials that occurred
\end{abstract}

Communicated by H. Cochard.

H. J. Renninger $(\square) \cdot$ N. Phillips

Department of Geography and Environment,

Boston University, 675 Commonwealth Ave.,

Boston, MA 02215, USA

e-mail: heidiren@bu.edu

N. Phillips

e-mail: nathan@bu.edu

D. R. Hodel

Cooperative Extension, University of California,

4800 E. Cesar Chavez Ave., Los Angeles, CA 90022, USA

e-mail: drhodel@ucdavis.edu earlier in the day and fewer, smaller leaves than did shorter palms. Leaf epidermal cells were also smaller in taller palms compared with shorter ones. These findings are consistent with hydraulic compensation in that tall palms may be overcoming the increased path length resistance through smaller, more efficient leaves and lower leaf water potentials than shorter palms.

Keywords HLH - Stomatal conductance - Sap flow · Leaf water potential $\cdot$ Mexican fan palm $\cdot$ LMA

\section{Introduction}

It has been frequently observed that as trees mature, height growth reaches a peak, at which point rates begin to decrease (Barnes et al. 1998; McDowell et al. 2002a; Litvak et al. 2003; Bond-Lamberty et al. 2004; Koch et al. 2004). There have been several proposed hypotheses regarding forest growth decline and, in particular, why tree height growth may begin to decline as trees get older and taller, including increased respiration (Ryan and Waring 1992), differences in the vigor of older tissues relative to younger ones (Mencuccini et al. 2005; Bond et al. 2007; Vanderklein et al. 2007) and increased mechanical stresses (Meng et al. 2006). However, there are several promising studies that suggest that hydraulic limitation may not only explain why height growth in tall trees is limited (Ryan and Yoder 1997) but could be used to predict maximum heights of a given tree species growing under given environmental conditions (Koch et al. 2004; Burgess and Dawson 2007). The hydraulic limitation hypothesis is built upon the idea that as trees get taller, not only does the hydrostatic gradient due to gravity increase, but the path length of water travel increases, with taller trees overcoming more friction 
in water transport than shorter trees. This means that taller trees are, by virtue of their height, less efficient at transporting water to their leaves relative to shorter trees. This lower efficiency could lead to lower stomatal conductance and, therefore, reduced photosynthesis and carbon gain (Ryan and Yoder 1997). Additionally, the turgor pressure at the tops of these trees will decrease, unless osmotic adjustment occurs, making cell expansion more difficult in developing leaves (Koch et al. 2004; Woodruff et al. 2004). Decreased turgor at the tops of the largest palms could therefore lead to decreases in leaf cell sizes and increases in leaf mass per unit area (LMA).

Studies in species ranging from ponderosa pine (Pinus ponderosa Dougl. ex C. Lawson) (Hubbard et al. 1999; Ryan et al. 2000), European beech (Fagus sylvatica L.) (Schäfer et al. 2000), eucalyptus (Eucalyptus saligna Sm.) (Barnard and Ryan 2003), Oregon white oak (Quercus garryana Dougl.) (Phillips et al. 2003a) and the tallest trees in the world, coastal redwoods [Sequoia sempervirens (D. Don) Endl.] (Koch et al. 2004) have found evidence that the hydraulic cost of increased frictional resistance reduced stomatal conductance in tall trees relative to shorter ones (reviewed in Ryan et al. 2006). However, there are other studies that suggest that the hydraulic costs that taller trees face can be offset by alterations in their architecture (Becker et al. 2000a). Also, theoretical models (West et al. 1999; Becker et al. 2000b) as well as empirical measurements show that hydraulic resistance due to path length can be significantly reduced (Weitz et al. 2006, Coomes et al. 2007), but in very tall trees not completely overcome (Anfodillo et al. 2006; Petit et al. 2008), by the tapering of vascular conduits along the length of trees. However, these compensatory features of taller trees are, in fact, consistent with the presence of hydraulic constraints to water transport in taller trees.

About $60-70 \%$ of studies that have measured one or more of the components of the hydraulic limitation hypothesis have found results that were consistent (Ryan et al. 2006), although several studies have provided some contradictory data (McDowell et al. 2002a; Barnard and Ryan 2003). One reason for the conflicting information could be the complexity of most tree systems. Their complicated branching patterns mean that each leaf on the tree will have a different path length from the ground. Also, the hydraulic architecture has been shown to be designed in such a way that branches receiving more sunlight are hydraulically favored over lower branches (Protz et al. 2000). Much of this complexity could be avoided if a simpler tree species such as palms were used to study hydraulic limitation. Palms represent a desirable tree form to use because, unlike most trees, they lack complex branching patterns and exhibit relatively fixed crown sizes (Zimmermann et al. 1982; Tomlinson 1990) making the path length of water flow as well as leaf area easily measurable. Additionally, hydraulic limitations in palms become especially important considering they lack secondary growth and may exhibit decreased functioning of xylem and phloem tissues with age (Zimmermann 1973). This is especially relevant for a palm species such as Washingtonia robusta where older, taller palms are likely to have experienced more frost episodes over their lifetime than younger, shorter palms and may not be able to refill embolized conduits (Sperry 1986). If vessels are able to refill, multiple freeze-thaw episodes have been shown to negatively affect the functioning of xylem tissues through cavitation fatigue, which may or may not be reversible (Hacke et al. 2001; Stiller and Sperry 2002).

We studied hydraulic limitation in Mexican fan palms, $W$. robusta $(\mathrm{H}$. Wendl.), a species that is naturally distributed throughout southern and central Baja California and western Sonora, Mexico along streams and canyons or near springs (Uhl and Dransfield 1987; Bullock and Heath 2006). Bullock and Heath (2006) studied W. robusta in the Baja California desert and estimate that they reach reproductive maturation at approximately $8 \mathrm{~m}$ tall with the tallest palms in their study being $32 \mathrm{~m}$. They also estimate the potential longevity of these palms to exceed 500 years. We hypothesize that hydraulic constraints on leaf gas exchange will increase with height in W. robusta with taller palms having lower sap flux per unit leaf area and lower stomatal conductance than shorter palms. Additionally, we are interested in any alterations in physiology or hydraulic architecture that tall palms exhibit in order to compensate for an increased path length of water flow relative to shorter palms; including changes in minimum leaf water potential, maximum photosynthetic rates, and leaf area to conducting area ratios. Not only could this research shed light on the physiological costs of increasing size in palms, but, because the biophysical variables we studied are also shared by woody plants, it may shed light on the physiological costs and compensations in tree species, in general, as they grow taller.

\section{Materials and methods}

\section{Site description}

This study was performed from 23 July to 3 August 2007 on ten individuals of $W$. robusta $(\mathrm{H}$. Wendl.) growing at the Los Angeles County Arboretum \& Botanic Garden $\left(34^{\circ} 8^{\prime} 29.43^{\prime \prime} \mathrm{N}, 118^{\circ} 3^{\prime} 15.15^{\prime \prime} \mathrm{W}\right)$ in Arcadia, California. The site contained several open-grown palm individuals scattered throughout a lawn with palms varying in height from $1 \mathrm{~m}$ tall to approximately $35 \mathrm{~m}$ tall. The site is adjacent to a natural aquifer; therefore, the water table is elevated in this location. Also, the area was sprinkler 
irrigated approximately three times per week for $1-2 \mathrm{~h}$ at each interval, and plants, therefore, should not have experienced soil moisture stress during the experimental period. Measurements of solar radiation were made using a pyranometer (Apogee Instruments, Roseville, CA, USA) located on an open lawn. Diurnal measures of temperature and relative humidity were made using a Campbell Scientific (CS215) temperature and relative humidity sensor (Campbell Scientific Inc., Logan UT, USA) located approximately $5 \mathrm{~m}$ above the ground in an exposed area. Atmospheric and radiation data were captured at intervals of $30 \mathrm{~s}$ and logged every 2 min using a CR10X datalogger and an associated AM16/32A multiplexer (Campbell Scientific Inc., Logan, UT, USA). For the 10 day measurement period, daily maximum temperatures ranged from 29 to $34^{\circ} \mathrm{C}$ and nightly minimum temperature ranged from 17 to $20^{\circ} \mathrm{C}$. Daily minimum humidity ranged from 21 to $50 \%$ and nightly maximum humidity ranged from 82 to $90 \%$. Daily maximum vapor pressure deficits (VPD) ranged from 2 to $4 \mathrm{kPa}$. Maximum daily solar radiative flux densities ranged from 850 to $1,060 \mathrm{~W} \mathrm{~m}^{-2}$.

\section{Palm height estimation}

Palm heights were estimated, with the aid of a tape measure, from the ground to the point at which the lowest leaves of the crown attached to the bole. Tall palms were accessed using a bucket lift. For shorter palms, height was estimated by making a mark on the bole $1 \mathrm{~m}$ above the ground, then estimating height by eye based on this mark. Because shorter palms tended to have more leaves, height was measured from the ground to the midpoint of the crown of leaves. The palm reported to be $2 \mathrm{~m}$ tall was a juvenile that did not possess a trunk; therefore its height was measured from the top of its leaves to the ground.

\section{Sap flux measurement}

Sap flux was measured in a total of ten palms in this study, ranging in height from 2 to $34 \mathrm{~m}$. Sap flux sensors were distributed as follows: sap flux sensors were installed in the boles of eight palms ranging from 7 to $34 \mathrm{~m}$ tall using $2 \mathrm{~cm}$ long Granier heat dissipation sensors (Granier 1987). Sap flux was also measured in the petioles in five palms ranging from $2 \mathrm{~m}$ tall to $34 \mathrm{~m}$ tall, in each of which two sap flux sensors were installed in two separate petioles. Table 1 summarizes tree data and sampling details.

In boles, the leaf bases (if any) were removed from the base of the palm and two sensors were installed on either side of the bole directly beneath the pseudobark, with this position indicated by a color change that was indicative of wet, conductive bole material. An additional sensor was also installed at a depth of $2 \mathrm{~cm}$ below the pseudobark, giving a total of three sensors per palm bole. Sensors were connected to a CR10X datalogger and an associated AM16/32A multiplexer that captured data at intervals of $30 \mathrm{~s}$ and logged every $2 \mathrm{~min}$ (Campbell Scientific Inc., Logan, UT, USA). The boles were wrapped with reflective insulation to prevent external temperature fluctuations. Data from outer bole sensors and the $2 \mathrm{~cm}$ depth sensor were pooled because statistical analysis indicated that they were not significantly different $(P$ value $=0.25)$. Sap flux data $\left(\mathrm{g} \mathrm{m}^{-2} \mathrm{~s}^{-1}\right)$ were scaled-up to the whole tree level by multiplying by the cross-sectional area of the bole minus the area of the pseudobark (approximated to be $1 \mathrm{~cm}$ thick) giving sap flux units of $\mathrm{kg} \mathrm{day}^{-1}$ and then divided by total palm leaf area to give units of $\mathrm{kg}$ day $^{-1} \mathrm{~m}^{-2}$ leaf area. We are assuming that sap flux is more or less constant across the radius of the bole (and indeed we found no significant differences between outer bole and $2 \mathrm{~cm}$ depth sensors). This assumption is also validated by work done by Roupsard et al. (2006) who found a constant pattern of sap flux throughout the stem of coconut palms (Cocos nucifera L.) up to a $12 \mathrm{~cm}$ radius. Likewise, Sellami and Sifaoui (2003) found that the sap flow in date palms (Phoenix dactylifera L.) did not differ significantly between the $3 \mathrm{~cm}$ and $6 \mathrm{~cm}$ depth sensors.

For the petiole sap flux, $1 \mathrm{~cm}$ long Granier sensors were only used in the petioles of the $2 \mathrm{~m}$ tall palm. All other petioles had $2 \mathrm{~cm}$ long Granier sensors. The shape of the petiole cross-section is approximately a semi-circle and sensors were inserted in the flat portion of the petiole (adaxial side). Petioles were then wrapped with reflective insulation to minimize external temperature fluctuations. Sap flux data $\left(\mathrm{g} \mathrm{m}^{-2} \mathrm{~s}^{-1}\right)$ were scaled-up by multiplying by the cross-sectional area of the petiole, giving sap flux units of $\mathrm{kg} \mathrm{day}^{-1}$ and then divided by individual frond leaf area to give units of $\mathrm{kg} \mathrm{day}^{-1} \mathrm{~m}^{-2}$ leaf area.

Stem water storage was also investigated in order to ascertain contributions of stored water in the bole to overall sap flux. Palms that are more reliant on stored bole water will tend to lag behind palms that have less stored bole water. To evaluate this, diurnal time courses of bole sap fluxes $\left(\mathrm{g} \mathrm{m}^{-2} \mathrm{~s}^{-1}\right)$ in two short palms ( 7 and $8 \mathrm{~m}$ ) were compared with diurnal time courses of bole sap fluxes $\left(\mathrm{g} \mathrm{m}^{-2} \mathrm{~s}^{-1}\right)$ in three tall palms $(28-34 \mathrm{~m})$ using cross-correlation analysis. In addition, two of the ten palms ( 8 and $28 \mathrm{~m}$ tall) had simultaneous bole and petiole sap flow data. In these individuals, stem water storage was estimated by pairing diurnal time courses of sap flux made in the bole with that of corresponding petioles using cross-correlation analysis. The time lag corresponding to the maximum degree of correlation between the petiole sap flux and the bole sap flux represented the approximate amount of water storage in the bole of the palm. 
Table 1 Basic characteristics of the Washingtonia robusta study palms including number and locations of Granier sensors for each individual

\begin{tabular}{lllll}
\hline $\begin{array}{l}\text { Height } \\
(\mathrm{m})\end{array}$ & $\begin{array}{l}\text { dbh } \\
(\mathrm{m})\end{array}$ & $\begin{array}{l}\text { Outer bole } \\
\text { sensors }\end{array}$ & $\begin{array}{l}\text { 2-cm depth } \\
\text { bole sensors }\end{array}$ & $\begin{array}{l}\text { Petioles } \\
\text { sensors }\end{array}$ \\
\hline 2 & - & - & - & 2 \\
7 & 0.52 & 2 & - & - \\
8 & 0.45 & 2 & 1 & 2 \\
9 & 0.47 & 2 & 1 & - \\
18 & 0.44 & 2 & 1 & 2 \\
22 & 0.43 & 2 & 1 & - \\
28 & 0.44 & 2 & 1 & 2 \\
30 & 0.57 & 2 & 1 & - \\
$34^{\mathrm{a}}$ & 0.51 & - & - & 2 \\
34 & 0.51 & 2 & 1 & - \\
\hline
\end{tabular}

${ }^{a}$ Leaning palm

Stomatal conductance and photosynthesis

Stomatal conductance and photosynthetic assimilation were measured diurnally on five palms ranging from 8 to $34 \mathrm{~m}$ tall using a LiCor 6400 photosynthesis system (Licor, Lincoln, NE, USA) fitted with a red-blue LED light source. Five palms were chosen from among the ten total palms to span a large range in height of reproductively mature individuals, and to maintain reasonable sampling time intervals throughout the day. Measurements were made over a 4 day period at intervals of approximately $1.5 \mathrm{~h}$ (from approx. 7 am to $5 \mathrm{pm}$ ) with a light level of $1,500 \mu \mathrm{mol} \mathrm{m} \mathrm{m}^{-2} \mathrm{~s}^{-1}$ and a $\mathrm{CO}_{2}$ level of $400 \mu \mathrm{mol} \mathrm{mol}^{-1}$. Two leaf segments from different fronds were measured per palm during each time period. Measurements were taken when both stomatal conductance and photosynthetic assimilation had stabilized. Measurements from the two leaf segments were averaged per time period. Polynomial equations were then fit to the diurnal stomatal conductance and photosynthetic assimilation data and were used to calculate maximum daily stomatal conductance and maximum daily photosynthetic assimilation rate (both calculated by setting the first derivative equal to zero) for each palm measured. Equations and $r^{2}$ values are presented in Table 2. With few exceptions, the rankings of maximum photosynthetic assimilation and maximum stomatal conductance across tree height were the same whether values were obtained from the polynomial equations or from the raw data.

Water potential measurement

Diurnal measures of leaf water potential were made on five palms ranging from 2 to $28 \mathrm{~m}$ tall using a Scholander type pressure chamber (Soil Moisture Equipment Corp., Santa Barbara, CA, USA)(Scholander et al. 1965). These individuals were selected from among the ten total palms to cover a large range in palm height but to maintain a manageable diurnal sampling schedule. Leaf water potentials were measured over a 4 day period at intervals of approximately $1.5 \mathrm{~h}$ (from approximately 6 am to $5 \mathrm{pm}$ ). Water potential measurements were made by removing two individual segments from the leaf. Leaf segments were immediately placed in a plastic bag and covered in order to promote stomatal closure and prevent further leaf dehydration. An approximately $1 \mathrm{~cm}$ length of leaf tissue was removed from either side of the midrib, and the remainder of the segment was placed in the pressure chamber with the midrib exposed to the outside environment. Measurements from the two leaf segments were averaged to give one measurement per palm at a given time period. Polynomial equations were then fit to the diurnal leaf water potential data and were used to calculate minimum leaf water potential and the time of minimum leaf water potential (both calculated by setting the first derivative equal to zero) for each palm. Equations and $r^{2}$ values are presented in Table 2. The rankings of minimum leaf water potential across tree height were the same whether values were obtained from the polynomial equations or from the raw data.

Table 2 Equations and $r^{2}$ values for the regressions in Fig. 3

\begin{tabular}{|c|c|c|c|c|c|c|}
\hline $\begin{array}{l}\text { Tree height } \\
\text { (m) }\end{array}$ & $\begin{array}{l}\text { Stomatal conductance } \\
\mathrm{mol} \mathrm{H}_{2} \mathrm{O}\left(\mathrm{m}^{-2} \mathrm{~s}^{-1}\right)\end{array}$ & $r^{2}$ & $\begin{array}{l}\text { Photosynthetic assimilation } \\
\mu \mathrm{mol} \mathrm{CO}_{2}\left(\mathrm{~m}^{-2} \mathrm{~s}^{-1}\right)\end{array}$ & $r^{2}$ & $\begin{array}{l}\text { Leaf water } \\
\text { potential (Mpa) }\end{array}$ & $r^{2}$ \\
\hline 2 & & & & & $y=-2.3+0.5 x-0.02 x^{2}$ & 0.87 \\
\hline 8 & $y=-1.28+0.26 x-0.01 x^{2}$ & 0.81 & $y=-38+8.1 x-0.32 x^{2}$ & 0.64 & $y=-8.9+1.7-006 x^{2}$ & 0.94 \\
\hline 18 & $y=-1.17+0.29 x-0.01 x^{2}$ & 0.6 & $y=4.67+1.6 x-0.08 x^{2}$ & 0.13 & $y=-4.8+1.1 x-004 x^{2}$ & 0.62 \\
\hline 22 & $y=-0.70+0.20 x-0.009 x^{2}$ & 0.33 & $y=6.4+1.5 x-0.06 x^{2}$ & 0.05 & $y=-8.1+16 x-0.06 x^{2}$ & 0.82 \\
\hline 28 & $y=-1.05+0.25 x-0.01 x^{2}$ & 0.67 & $y=-37+8.2 x-0.32 x^{2}$ & 0.63 & $y=-9.8+1.9 x-007 x^{2}$ & 0.9 \\
\hline $34^{\mathrm{a}}$ & $y=-1.16+0.24 x-0.01 x^{2}$ & 0.66 & $y=-55+11 x-042 x^{2}$ & 0.96 & & \\
\hline
\end{tabular}

${ }^{a}$ Leaning palm 


\section{Leaf characteristics}

Leaf areas were estimated for the same two leaves used to measure petiole sap flux in four of the ten study palms ranging from 8 to $34 \mathrm{~m}$ tall. These palms represented a range of heights and could be accessed using the bucket lift or ladder. Leaves were harvested after sap flux measurement had been completed and an overhead digital photo was taken of each leaf with a known scaling factor. Image analysis software (Image J, Scion Image, Frederick, MD, USA) was then used to measure leaf area. Measurements of the two leaves were pooled to give an average leaf area for each palm. In order to measure leaf dry mass per unit area (LMA), three leaf segments from each leaf were removed and their individual areas measured. These leaf segments were allowed to air dry for 1 week, then their dry weight was obtained. Additionally, live leaf counts were made on each individual.

Leaf epidermal cell sizes, stomatal density and guard cell length were measured by making hand sections of leaf material. To begin, individual leaf segments were gathered from palms 2 to $34 \mathrm{~m}$ tall, and then thin sections were cut with a razor blade from the adaxial side of two individual leaf segments tangential to the midrib. Sections were then stained with a solution of $1 \%$ Toluidine Blue $\mathrm{O}$ and mounted on slides using Permount. The slides were viewed at $200 \times$ magnification using a compound light microscope (Nikon Alphaphot-2, Melville, NY, USA) and photographs were taken with a digital camera (Fuji FinePix F700 Valhalla, NY, USA). These photographs were imported into image analysis software (Image J, Scion Image, Frederick, MD, USA) for measurement. Leaf epidermal cell areas were measured by tracing around the perimeter of approximately 20-30 cells per photograph and calculating the area of this traced section. Approximately 2-5 photographs per palm were used for this measurement giving a total of approximately $50-150$ cells measured per palm. Stomatal densities were calculated by counting the number of stomata within a field of view, then calculating the area of that field of view. Approximately 15-20 different fields of view were used per palm. Guard cell lengths were calculated by measuring the distance between the two points where the guard cells meet. Approximately 50 and 100 stomata were measured per palm in order to calculate average guard cell length.

\section{Statistical analyses}

Means, standard errors and Tukey HSD tests were calculated using JMP 7.0 statistical software (SAS Institute, Cary, NC, USA). All linear and polynomial regressions were fitted using SigmaPlot 2000 Version 6.1 (SPSS Inc., Chicago, IL, USA) software. $R^{2}$ and $P$ values for all regressions were also calculated using SigmaPlot 2000.

\section{Results}

Palms were found to range in height from $2 \mathrm{~m}$ tall to $34 \mathrm{~m}$ tall. Due to its significant lean, the crown of one of the palms reported to be $34 \mathrm{~m}$ tall was only $27 \mathrm{~m}$ about the ground. However, because hydraulic limitation is concerned with friction imposed on water travel as well as hydrostatic gradients in water potential, trunk length is as important in this study as actual crown height above the ground. All other palms did not possess a significant lean. The palm reported to be $2 \mathrm{~m}$ tall was a juvenile that did not possess a trunk therefore, because this individual differed so greatly in development from the other individuals, only petiole sap flux, water potentials and leaf epidermal cell areas were compared with taller palms, and only to make limited inferences (in "Discussion").

Representative diurnal time courses of bole sap flux $\left(\mathrm{g} \mathrm{m}^{-2} \mathrm{~s}^{-1}\right)$ in palms ranging in height from 7 to $34 \mathrm{~m}$ tall are presented in Fig. 1 with corresponding VPD and solar radiation time data. Daily minimums, maximums, means and standard errors for the palms studied are presented in Table 3. There is a slight positive relationship between palm height and daily bole sap flux per unit leaf area (Fig. 2a; $P=0.06, r^{2}=0.46$ ) due to the decrease in leaf area with increases in palm height, but no relationship between palm height and daily petiolar sap flux per unit leaf area (Fig. $2 b ; P$ value $=0.54$ ). Variability in $W$. robusta sap flux both within and between palms was considerable with bole sap flux per unit leaf area differing by up to a factor of about three and petiole sap flux per unit leaf area differing by almost a factor of about six. Roupsard et al. (2006) also found large variability in coconut palms with sap flow varying by up to a factor of three between palms.

Investigation of stem water storage using between palm cross-correlation analysis indicated that bole sap flux in large palms lagged behind bole sap flux of small palms by 30 min $\left(n=4\right.$ palms; maximum $\left.r^{2}=0.68\right)$. Similarly, within-palm cross-correlation analysis indicated a larger petiole-bole time lag in a larger palm (44 min lag in a $28 \mathrm{~m}$ tall palm; maximum $r^{2}=0.87$ ) than a shorter palm (28 min lag in an $8 \mathrm{~m}$ tall palm; maximum $r^{2}=0.8$ ). These lags correspond to approximately 16 and $22 \%$ of daily water use, respectively, according to procedures and assumptions described in Phillips et al. (2003b).

Daily maximum stomatal conductances and photosynthetic assimilation rates were calculated from the curves shown in Fig. 3a, b and equations with $r^{2}$ values are presented in Table 2. Maximum daily stomatal conductance showed no discernable relationship with tree height (Fig. $4 \mathrm{a} ; P$ value $=0.36$ ). Additionally, there was no observable relationship between tree height and either stomatal density $(P$ value $=0.82)$ or guard cell length 


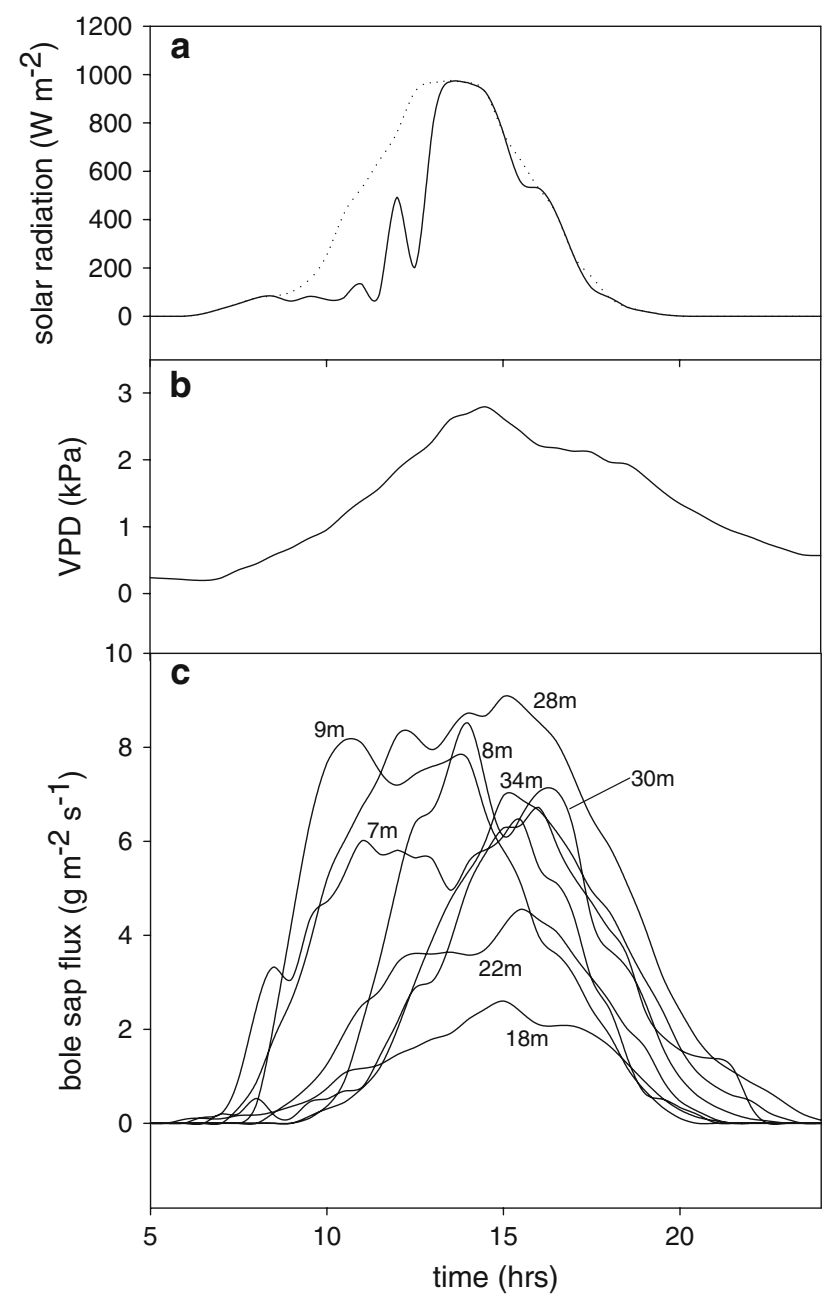

Fig. 1 Representative diurnal sap flux $\left(\mathrm{g} \mathrm{m}^{-2} \mathrm{~s}^{-1}\right.$ ) (bottom panel) on Julian day 210 from a single outer sapflow sensor for eight individuals of varying heights. The middle panel represents vapor pressure deficit $(V P D)(\mathrm{kPa})$ and the top panel represents solar radiative flux density $\left(\mathrm{W} \mathrm{m} \mathrm{m}^{-2}\right)$. The solar flux sensor was shaded early in the morning, therefore solar radiation measurements are artificially low in this time interval. The dotted line represents a clear-day estimate of solar radiation and the likely light environment for the crowns of the palms

$(P$ value $=0.86) \quad($ data not shown $)$. Maximum daily photosynthetic assimilation rate exhibited a positive linear correlation with tree height (Fig. $4 \mathrm{~b} ; r^{2}=0.80$, $P$ value $=0.041)$ with taller palms exhibiting higher photosynthetic rates than shorter palms. There was no observable relationship between LMA and tree height (Fig. 4c; $P$ value $=0.19$ ) and individuals did not differ significantly from one another.

Minimum leaf water potentials and the timing of minimum leaf water potentials were calculated from the curves shown in Fig. 3c and equations with $r^{2}$ values are presented in Table 2. Minimum leaf water potentials were significantly and non-linearly correlated with tree height (Fig. 5a; $r^{2}=0.97, P$ value $\left.=0.0234\right)$ with taller palms generally having more negative minimum leaf water potentials than shorter palms; although the slope of the curve decreases with increasing height. Also, the time of minimum leaf water potential was negatively correlated with tree height (Fig. $5 \mathrm{~b} ; r^{2}=0.61, P$ value $=0.12$ ) with taller palms reaching a minimum leaf water potential earlier in the day than shorter palms. Because all individuals were opengrown, it is unlikely that differences in the timing of minimum leaf water potential were the result of differences in solar radiation throughout the day. The earliest minimum leaf water potential (in the tallest palm) was reached at approximately 13:42 PDT and the latest minimum leaf water potential (in the shortest palm) was reached at 16:36 PDT $($ mean $=14: 42$ PDT, $S E=29$ min). Although the $2 \mathrm{~m}$ tall palm was still a juvenile and therefore differed developmentally from the other individuals, we feel that comparisons of leaf water potential are still valid.

Leaf areas were significantly and negatively correlated with tree height. Taller palms had fewer leaves (Fig. 6a; $r^{2}=0.6, P$ value $\left.=0.026\right)$ and leaves with smaller areas (Fig. $6 \mathrm{~b} ; r^{2}=0.99, P$ value $=0.058$ ) than shorter palms; although both of these relationships were non-linear with the slope of the curve decreasing as tree height increased. Leaf epidermal cell sizes were found to remain constant in palms $2 \mathrm{~m}$ tall to $22 \mathrm{~m}$ tall with Tukey HSD tests confirming that cell sizes in these palms did not differ significantly from one another at a 95\% confidence level (Fig. 6c). On the other hand, leaf epidermal cell sizes in both $28 \mathrm{~m}$ tall palms and $34 \mathrm{~m}$ tall palms were found to be significantly smaller $(P$ values $<0.05)$ than in palms $2-$ $22 \mathrm{~m}$ tall. Additionally, leaf epidermal cells from the $34 \mathrm{~m}$ tall palm were found to be significantly smaller than cells from the $28 \mathrm{~m}$ tall palm (Fig. 6c; $P$ value $<0.001$ ).

\section{Discussion}

The hydraulic limitation hypothesis states that as trees grow taller, greater friction to water flow causes taller trees to reach minimum leaf water potentials sooner in the day than shorter trees causing stomatal closure that decreases carbon gain (Yoder et al. 1994; Ryan and Yoder 1997). However, W. robusta palms showed no discernable decrease in daily bole sap flux per unit leaf area, daily petiolar sap flux per unit leaf area, maximum stomatal conductance, stomatal densities or stomatal sizes with an increase in tree height suggesting that taller palms are not experiencing the effects of hydraulic limitation. Barnard and Ryan (2003) also found that taller Eucalyptus trees had similar sap flux per unit leaf area and whole tree stomatal conductance compared to their shorter counterparts. McDowell et al. (2002a) found similar results in oldgrowth Douglas-fir trees, in that stomatal conductance, 
Table 3 Maximum, minimum, mean and std. errors for the various physiological variables measured across palm height where $n$ represents the number of palms sampled for a given variable

\begin{tabular}{|c|c|c|c|c|c|}
\hline & $n$ & Maximum & Minimum & Mean & Std error \\
\hline Daily bole sap flux ( $\mathrm{kg}$ day ${ }^{-1} \mathrm{~m}^{-2}$ leaf area) & 8 & 0.5 & 1.7 & 1.0 & 0.2 \\
\hline Daily petiole sap flux $\left(\mathrm{kg} \mathrm{day}^{-1} \mathrm{~m}^{-2}\right.$ leaf area) & 5 & 0.2 & 1.3 & 0.8 & 0.1 \\
\hline Max. daily stomatal conduct. ( $\mathrm{mol} \mathrm{H}_{2} \mathrm{O} \mathrm{m}^{-2} \mathrm{~s}^{-1}$ ) & 5 & 0.32 & 0.66 & 0.42 & 0.052 \\
\hline Stomatal density (stomata $\mathrm{mm}^{-2}$ ) & 6 & 150 & 300 & 210 & 21 \\
\hline Guard cell length $(\mu \mathrm{m})$ & 6 & 13 & 19 & 16 & 0.9 \\
\hline Max. daily photo. assim. $\left(\mu \mathrm{mol} \mathrm{CO}_{2} \mathrm{~m}^{-2} \mathrm{~s}^{-1}\right)$ & 5 & 13 & 19 & 15.7 & 1 \\
\hline $\operatorname{LMA}\left(\mathrm{g} \mathrm{m}^{-2}\right)$ & 6 & 179 & 225 & 201 & 7.6 \\
\hline Minimum leaf water potential (Mpa) & 5 & -2.0 & -3.6 & -3.0 & 0.27 \\
\hline Leaf area $\left(\mathrm{m}^{2}\right)$ & 4 & 0.79 & 1.74 & 1.13 & 0.21 \\
\hline Live leaf number per palm & 10 & 18 & 33 & 23 & 1.5 \\
\hline Leaf epidermal cell sizes $\left(\mu \mathrm{m}^{2}\right)$ & 6 & 196 & 306 & 263 & 16.5 \\
\hline
\end{tabular}

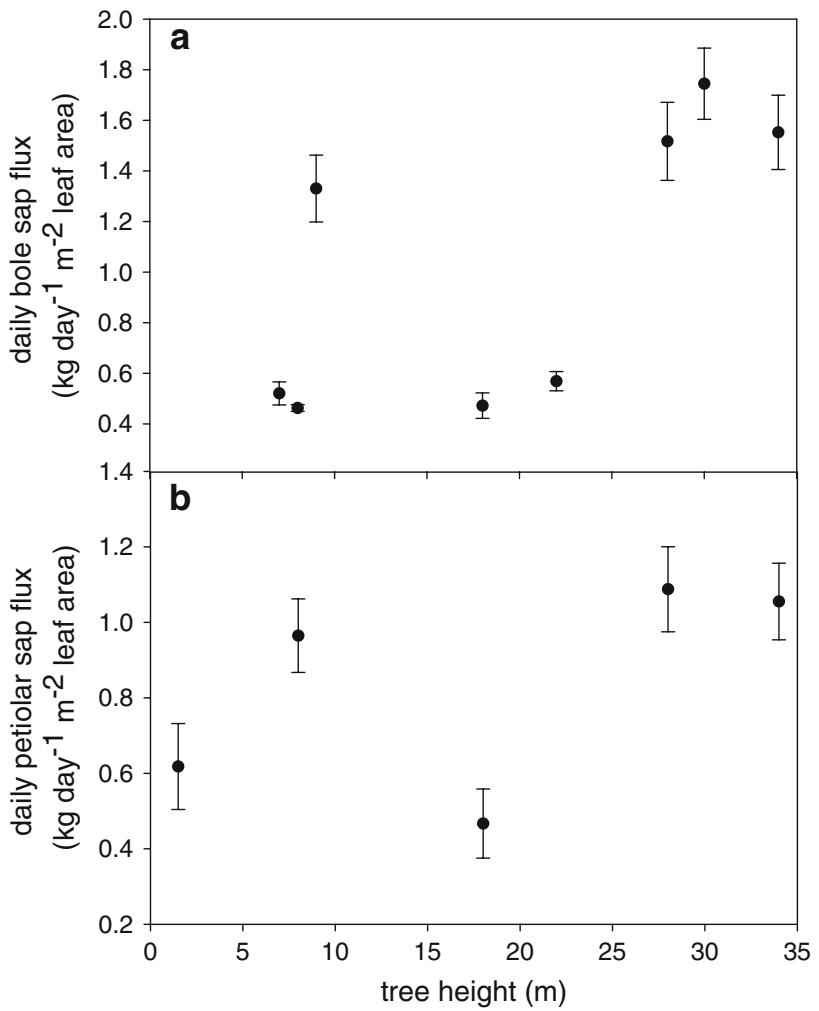

Fig. 2 Tree height $(\mathrm{m})$ versus means and standard errors of a total daily bole sap flux $\left(\mathrm{kg}\right.$ day ${ }^{-1} \mathrm{~m}^{-2}$ leaf area) and $\mathbf{b}$ total daily petiolar sap flux $\left(\mathrm{kg}\right.$ day ${ }^{-1} \mathrm{~m}^{-2}$ leaf area). For bole sap flux, standard error bars represent $4-8$ replicate days and 2 or 3 sensor locations. For petiole sap flux, standard error bars represent 3 replicate days and 2 petioles

photosynthetic assimilation and leaf-specific hydraulic conductance were not significantly different among trees of different heights.

Although hydraulic limitation was not observed in W. robusta in terms of lower stomatal conductance in taller palms, we found several alterations in physiology with height including decreasing leaf area, decreasing leaf cell sizes and more negative midday leaf water potentials suggesting that tall palms face, and in turn compensate for, some degree of hydraulic path length constraint. For example, taller palms reached a minimum leaf water potential sooner in the day than shorter palms. Because all individuals were open-grown, it is unlikely that differences in the timing of minimum leaf water potential were the result of differences in solar radiation throughout the day. The timing of minimum leaf water potential may have been even more disparate had all palms exhibited the same minimum leaf water potential. However, as with many other studies of trees across a height gradient (McDowell et al. 2002a; Barnard and Ryan 2003; Woodruff et al. 2007), taller palms also exhibited more negative minimum leaf water potentials than shorter trees. It is interesting that taller palms would be able to withstand more negative water potentials than shorter palms and it begs the question; Why do shorter palms not keep their stomata open longer and reach the minimum water potentials that tall palms do? One reason could be that the petiole xylem of taller palms is more resistant to cavitation than petioles of shorter palms. Woodruff et al. (2007) found minimum leaf water potentials were highly correlated with the water potential at which leaves lost hydraulic conductance along a height gradient. Their finding implies that not only do the leaves at the top of tall trees keep their stomata open at more negative leaf water potentials, but stomatal closure could be correlated to a loss of leaf hydraulic conductance.

Lower leaf water potentials were one way in which taller palms compensate for a longer path length of water travel. However, in order to sustain these more negative water potentials, leaf cells in taller trees may have had to increase their osmotic potential in order to maintain turgor (Meinzer et al. 2008). This additional carbon requirement 


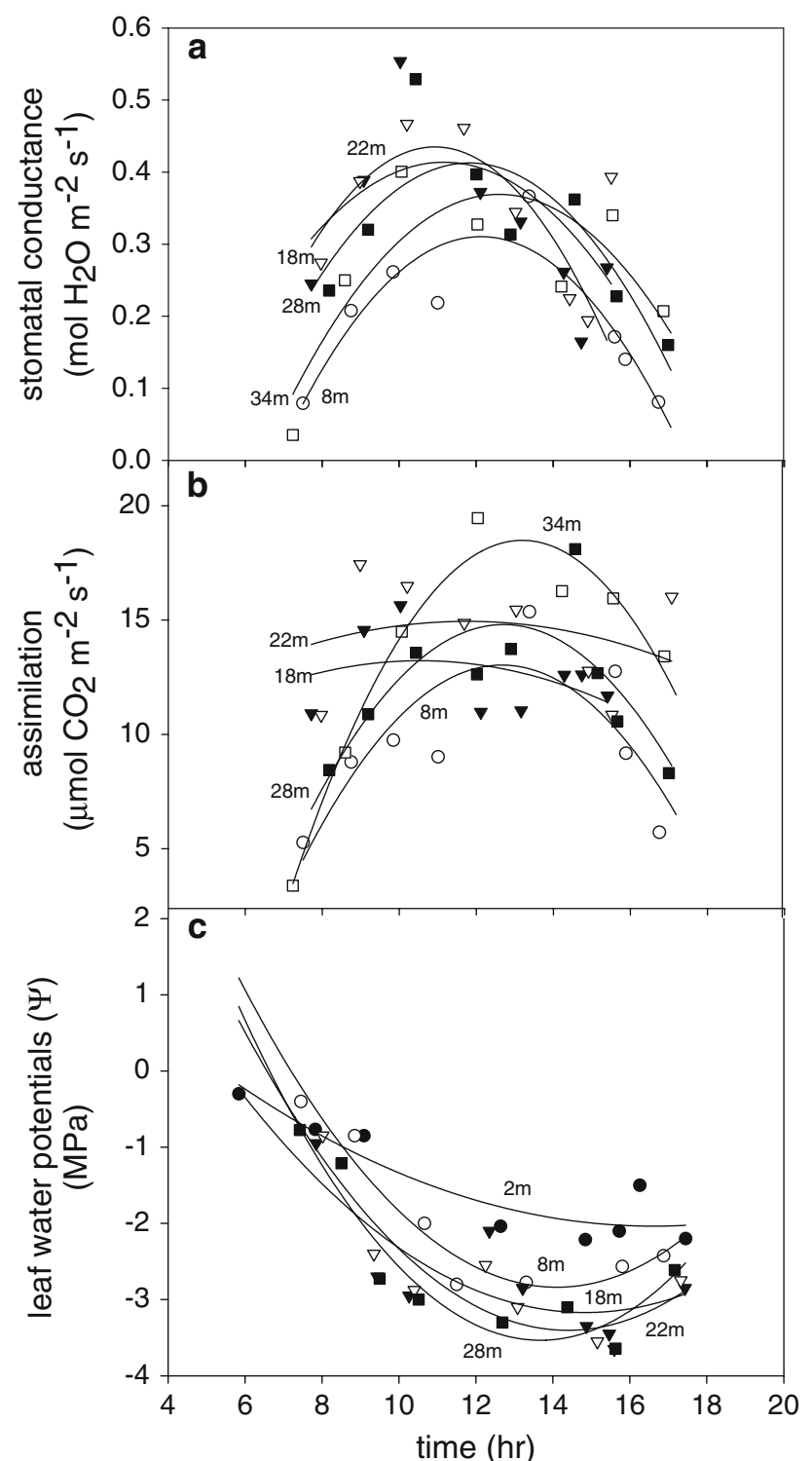

Fig. 3 Daily time courses of a stomatal conductance $\left(\mathrm{mol} \mathrm{H}_{2} \mathrm{O}\right.$ $\left.\mathrm{m}^{-2} \mathrm{~s}^{-1}\right)$, b photosynthetic assimilation rate $\left(\mu \mathrm{mol} \mathrm{CO}_{2} \mathrm{~m}^{-2} \mathrm{~s}^{-1}\right)$ and $\mathbf{c}$ leaf water potentials ( $\Psi, \mathrm{MPa})$. Closed circles $2 \mathrm{~m}$ palm, open circles $8 \mathrm{~m}$ palm, closed triangles $18 \mathrm{~m}$ palm, open triangles $22 \mathrm{~m}$ palm, closed squares $28 \mathrm{~m}$ palm, open squares $34 \mathrm{~m}$ leaning palm. Equations and $r^{2}$ values are presented in Table 2

in taller palms could negatively affect increased height growth. It is also interesting to note that differences in minimum leaf water potential between the $8 \mathrm{~m}$ tall palm and the $28 \mathrm{~m}$ tall palm are approximately $0.4 \mathrm{MPa}$, and we would expect the taller palm to exhibit, at minimum, a decrease of $0.2 \mathrm{MPa}$, simply due to the hydrostatic gradient alone (i.e. if there were zero frictional resistance). Therefore, about half of the difference in leaf water potential between the $8 \mathrm{~m}$ tall palm and the $28 \mathrm{~m}$ tall palm is a consequence of moving water against gravity with the other half likely resulting from the added friction to the water column given the increased path length.

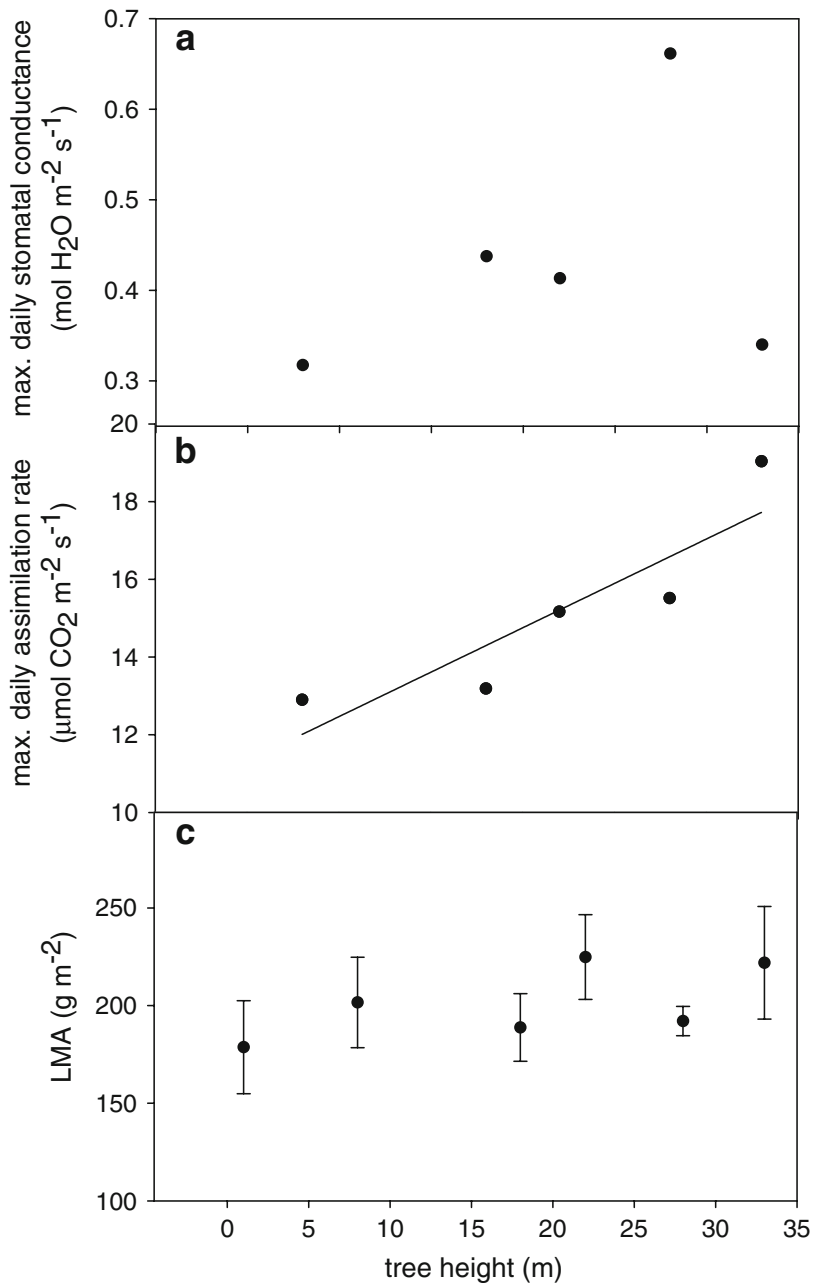

Fig. 4 Tree height (m) versus a maximum daily stomatal conductance ( $\mathrm{mol} \mathrm{H}_{2} \mathrm{O} \mathrm{m}^{-2} \mathrm{~s}^{-1}$ ) calculated from the daily time courses of stomatal conductance (Fig. 3a), b maximum daily photosynthetic assimilation rate $\left(\mu \mathrm{mol} \mathrm{CO} \mathrm{CO}^{-2} \mathrm{~s}^{-1}\right)$ calculated from the daily time courses of photosynthetic assimilation rate (Fig. 3b) $(y=0.23 x+10.2)$ and $\mathbf{c}$ mean leaf mass per area $\left(L M A ; \mathrm{g} \mathrm{m}^{-2}\right)$ where std. error bars represent five replicate leaflets

Another compensation that trees can make to offset hydraulic limitation is to alter their hydraulic architecture so that they have less leaf area for a given unit of sapwood area that needs to be supplied with water. For many palm species including $W$. robusta, bole diameters remain more or less constant across various heights once their stems reach maximum diameter and begin to elongate vertically. Likewise, palm species do not lose conducting area of their boles through the formation of heartwood. Therefore, any changes in hydraulic architecture in this and many other palm species occur mainly through changes in leaf area. In our study, not only did taller palms have fewer leaves than shorter palms, but the leaves they had were smaller in area. This is unlikely to be influenced by light environment since all individuals were open-grown. Decreases in leaf area to 


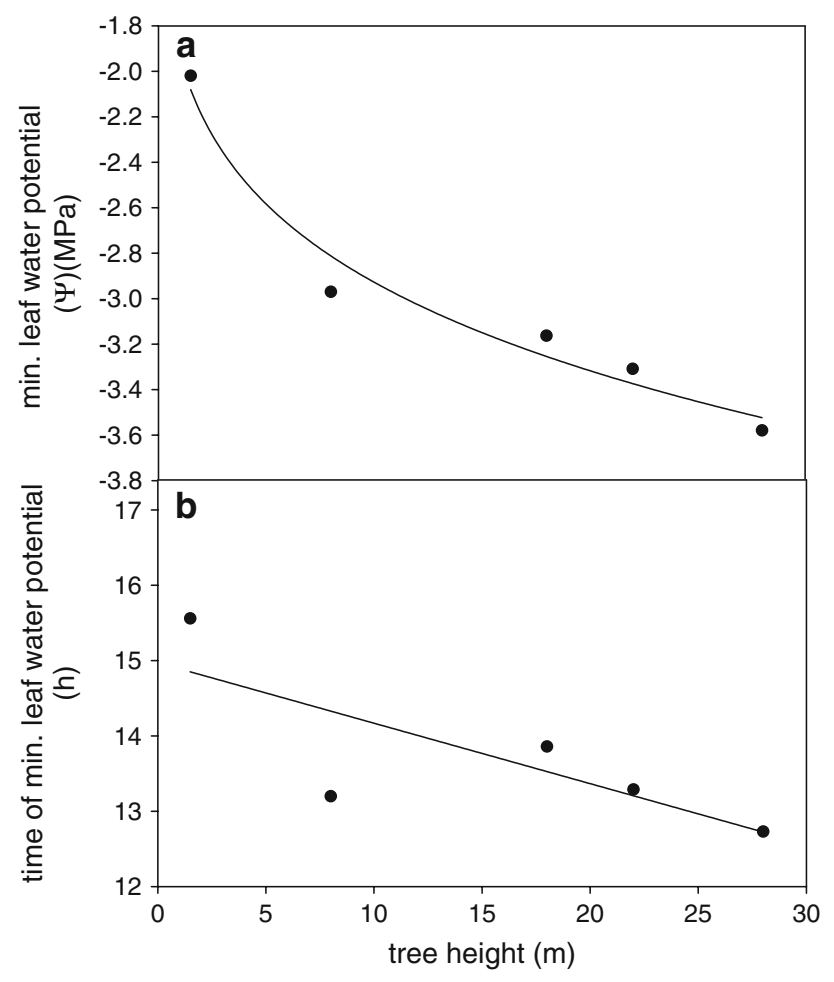

Fig. 5 Tree height $(\mathrm{m})$ versus a minimum daily leaf water potential ( $\Psi$; MPa $\left(y=-1.9 x^{0.18}\right)$ and $\mathbf{b}$ the time at which minimum leaf water potential occurred $(y=0.08 x+16.0)$, both calculated from the daily time courses of leaf water potential (Fig. 3c)

sapwood area ratios across height has been seen in several other studies (Schäfer et al. 2000; Phillips et al. 2001; McDowell et al. 2002b; Barnard and Ryan 2003), although there are some exceptions to this trend (Phillips et al. 2003a). Specifically, Buckley and Roberts (2006) predict that leaf area to sapwood area ratios should increase with height growth (until height growth tapers off) in order to maximize carbon gain. Of course, these decreases in leaf area may also be the result of a mechanical limitation and not a hydraulic one since a smaller crown would put less strain on the bole than a larger, heavier one.

Not only do taller trees face an increased path length to water flow but the turgor pressures at the tops of these trees will also decrease unless osmotic adjustment occurs (Koch et al. 2004; Woodruff et al. 2004). This decreased turgor pressure could lead to more limited cell expansion at the tops of tall trees relative to shorter ones (Woodruff et al. 2004) and increased LMA (Marshall and Monserud 2003; Koch et al. 2004). However, we found no significant differences in LMA between palms of different heights. LMA may be consistent across palm height because all palms were opengrown and it has been observed that LMA is affected by light availability (Bond et al. 1999) as well as tree height. We did, however, find that the tallest palms ( 28 and $34 \mathrm{~m}$ tall) had smaller epidermal cells than shorter palms, potentially due

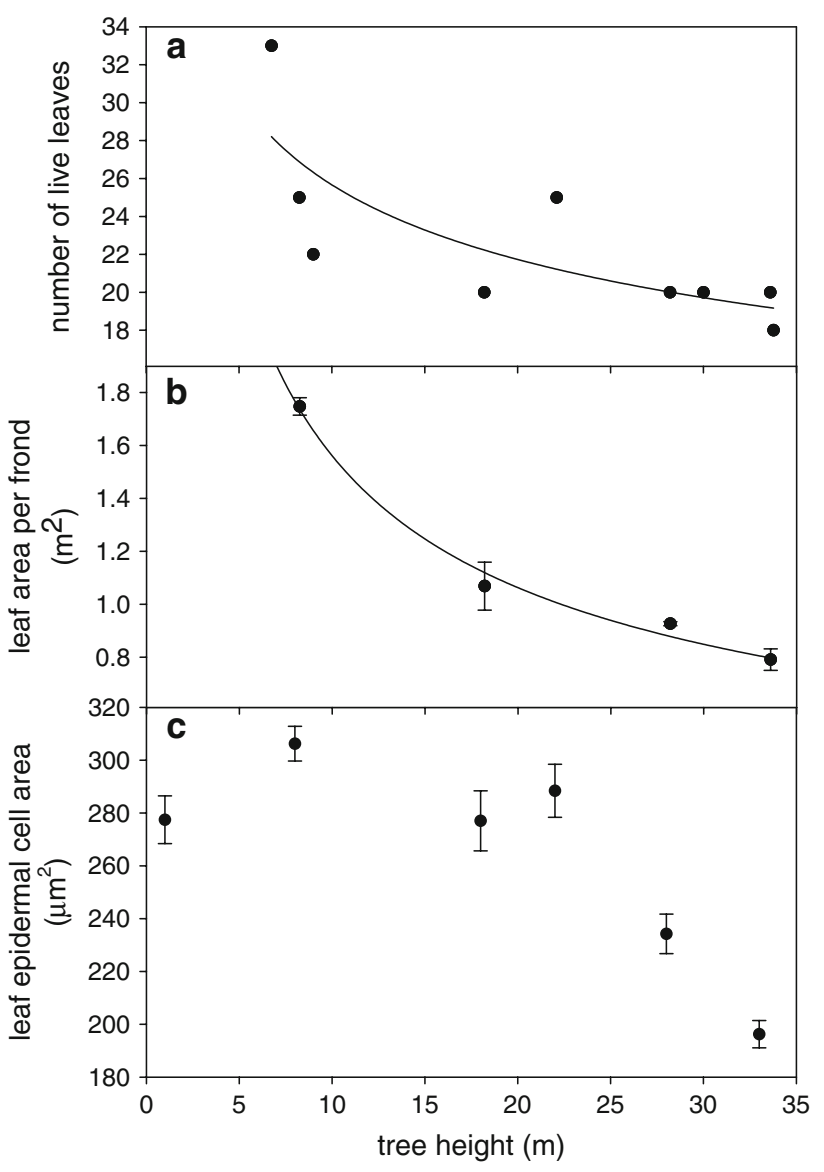

Fig. 6 Tree height (m) versus a the number of live leaves per palm $\left(y=44.6 x^{-0.24}\right)$, b leaf area $\left(\mathrm{m}^{2}\right)\left(y=5.59 x^{-0.55}\right)$ and $\mathbf{c}$ average leaf epidermal cell area $\left(\mu \mathrm{m}^{2}\right)$ for a given leaf. Errors bars represent the standard error from the two leaves per palm measured and the standard error around average leaf epidermal cell size. Leaf epidermal cell sizes for the 28 and $34 \mathrm{~m}$ palms are significantly lower than the shorter palms and well as being significantly different from each other $(P$ value $<0.05)$

to a decreased turgor pressure in these cells during expansion. It is also interesting to note that although epidermal cells were significantly smaller in taller palms than shorter ones, guard cell sizes showed no pattern of decrease with height. In addition, although taller palms had less leaf area than shorter palms, their leaves increased in photosynthetic capacity, exhibiting higher maximum daily photosynthetic assimilation rates than did those of shorter palms. This higher photosynthetic capacity could offset some of the carbon gain lost by having smaller leaf areas.

Taller palms also appeared to exhibit greater stem water storage, both in cross-correlation analysis of basal bole sap flux between taller and shorter palms and in cross-correlation analysis between petioles and boles and this trend has been seen in other studies as well (Goldstein et al. 1998; Phillips et al. 2003b). Specifically for palms, Holbrook and Sinclair (1992) found that water storage per unit leaf area within the stem increased linearly with palm height in Sabal 
palmetto ((Walt.) Lodd). However, this pattern may not hold true in all palm species with Rich (1987) finding that wet density of the central tissue in Iriartea gigantea $(\mathrm{H}$. A. Wendl. ex Burret) palms decreased with individual height and that water content decreased from 90 to $25 \%$ by weight in peripheral tissues and from 95 to $90 \%$ in the central tissues as tree height increased. For most tree species, increases in stem water storage occur mainly through increases in diameter. However, in palms, which exhibit more or less constant bole diameters, increases in stem water storage can still be achieved through increases in height and changes in stem tissue properties.

In summary, although $W$. robusta palms in this study were some of the tallest known palms of this species in the Los Angeles area, we found no evidence that hydraulic limitation was impacting stomatal conductance, at least on a per unit leaf area basis. There was a large amount of variability in bole and petiole sap flux that could be masking any trends in sap flux with height, however, our sap flux data agrees with independently measured stomatal conductance data in finding no negative relationship in stomatal conductance with height. One reason that palms may not exhibit hydraulic limitations with height could be due to their hydraulic architecture. The bole-frond junction is a point of large resistance because only the small vessels of the protoxylem connect the bole with the frond (Tomlinson 1990). Because the major point of hydraulic resistance in palms exists at this bole-frond connection, palms may be able to increase the length of their boles without incurring the costs of increased friction normally associated with hydraulic limitation with height (Noel Michele Holbrook, personal communication). We did find, however, that taller palms had lower minimum leaf water potentials that occurred earlier in the day than in shorter palms. Also, taller palms had fewer, smaller leaves that were more photosynthetically efficient than did shorter palms. Therefore, although carbon gain was not more stomatally limited in taller palms than in shorter palms, they did exhibit lower leaf areas than shorter palms which could limit their overall carbon gain (Phillips et al. 2003a) and therefore limit subsequent increases in height. Alternatively, decreased height growth rates in tall palms could be a response to mechanical limitation. Palms at their maximum height have been shown to have a lower margin of safety against mechanical failure than both shorter palms as well as angiosperm and conifer species (Rich et al. 1986; Rich 1987). Although not studying palm species, Meng et al. (2006) found that by tethering tall lodgepole pines (Pinus contorta Dougl.) to reduce their bending movement, the trees increased their height growth by $40 \%$ relative to the previous, untethered period. Lower leaf areas in taller palms may, in fact, be a response to mechanical limitation as well as hydraulic limitation with one or both of these factors explaining the decreased height growth rates exhibited by tall W. robusta palms.

Acknowledgments The authors thank Mark Wourms (CEO) and Tim Phillips (superintendent) of the Los Angeles County Arboretum $\&$ Botanic Garden for access to the site and the studied palms as well as the staff of the Arboretum for all of the help they provided. We are grateful to Patrick Mahoney, owner of West Coast Arborists, Inc. of Anaheim, California, for the donated use of a bucket lift and operators Manuel Diaz and Eduardo Martinez for operation of the lift. We thank Diane Pataki and Heather McCarthy of University of California, Irvine for discussion and use of field equipment. We thank Mikael Salazar and Cindy Basco for hospitality in providing food and lodging during the field campaign. This work was funded through a grant from the National Science Foundation (IOB \#0517521).

Open Access This article is distributed under the terms of the Creative Commons Attribution Noncommercial License which permits any noncommercial use, distribution, and reproduction in any medium, provided the original author(s) and source are credited.

\section{References}

Anfodillo T, Carraro V, Carrer M, Fior C, Rossi S (2006) Convergent tapering of xylem conduits in different woody species. New Phytol 169:279-290. doi:10.1111/j.1469-8137.2005.01587.x

Barnard HR, Ryan MG (2003) A test of the hydraulic limitation hypothesis in fast-growing Eucalyptus saligna. Plant Cell Environ 26:1235-1245. doi:10.1046/j.1365-3040.2003.01046.x

Barnes BV, Zak DR, Denton SR, Spurr SH (1998) Carbon balance of trees and ecosystems. In: Forest ecology, 4th edn. Wiley, New York, pp 486-523

Becker P, Meinzer FC, Wullschleger SD (2000a) Hydraulic limitation of tree height: a critique. Funct Ecol 14:4-11. doi: 10.1046/j.1365-2435.2000.00397.x

Becker P, Gribben RJ, Lim CM (2000b) Tapered conduits can buffer hydraulic conductance from path-length effects. Tree Physiol 20:965-967

Bond BJ, Farnsworth BT, Coulombe RA, Winner WE (1999) Foliage physiology and biochemistry in response to radiation gradients in conifers with varying shade tolerance. Oecologia 199(2):183192. doi: $10.1007 / \mathrm{s} 004420050847$

Bond BJ, Czarnomski N, Cooper C, Day ME, Greenwood MS (2007) Developmental decline in height growth in Douglas-fir. Tree Physiol 27:441-453

Bond-Lamberty B, Wang C, Gower ST (2004) Net primary production and net ecosystem production of a boreal black spruce wildfire chronosequence. Glob Change Ecol 10:473-487. doi: 10.1111/j.1529-8817.2003.0742.x

Buckley TN, Roberts DW (2006) How should leaf area, sapwood area, and stomatal conductance vary with tree height to maximize growth? Tree Physiol 26:145-157. doi:10.1093/ treephys/26.2.145

Bullock SH, Heath D (2006) Growth rates and age of native palms in the Baja California desert. J Arid Environ 67:391-402. doi: 10.1016/j.jaridenv.2006.03.002

Burgess SSO, Dawson TE (2007) Predicting the limits to tree height using statistical regression of leaf traits. New Phytol 174:626636. doi:10.1111/j.1469-8137.2007.02017.x

Coomes DA, Jenkins KL, Cole LES (2007) Scaling of tree vascular transport systems along gradients of nutrient supply and altitude. Biol Lett 3:87-90. doi:10.1098/rsbl.2006.0551 
Goldstein G, Andrade JL, Meinzer FC, Holbrook NM, Cavelier J, Jackson P, Celis A (1998) Stem water storage and diurnal patterns of water use in tropical forest canopy trees. Plant Cell Environ 21:397-406. doi:10.1046/j.1365-3040.1998.00273.x

Granier A (1987) Evaluation of transpiration in a Douglas-fir stand by means of sap flow measurements. Tree Physiol 3:309-320

Hacke UG, Stiller V, Sperry JS, Pittermann J, McCulloh KA (2001) Cavitation fatigue. Embolism and refilling cycles can weaken the cavitation resistance of xylem. Plant Physiol 125:779-786. doi: 10.1104/pp.125.2.779

Holbrook NM, Sinclair TR (1992) Water balance in the arborescent palm, Sabal palmetto. I. Stem structure, tissue water release properties and leaf epidermal conductance. Plant Cell Environ 15:393-399. doi:10.1111/j.1365-3040.1992.tb00989.x

Hubbard RM, Bond BJ, Ryan MG (1999) Evidence that hydraulic conductance limits photosynthesis in old Pinus ponderosa trees. Tree Physiol 19:165-172

Koch GW, Sillett SC, Jennings GM, Davis SD (2004) The limits to tree height. Nature 428:851-854. doi:10.1038/nature02417

Litvak M, Miller S, Wofsy SC, Goulden M (2003) Effect of stand age on whole ecosystem $\mathrm{CO}_{2}$ exchange in the Canadian boreal forest. J Geophys Res. doi:10.1029/2001JD000854

Marshall JD, Monserud RA (2003) Foliage height influences specific leaf area of three conifer species. Can J Res 33:164-170. doi: 10.1139/x02-158

McDowell NG, Phillips N, Lunch C, Bond BJ, Ryan MG (2002a) An investigation of hydraulic limitation and compensation in large, old Douglas-fir trees. Tree Physiol 22:763-774

McDowell NG, Barnard H, Bond BJ, Hinckley T, Hubbard RM, Ishii H, Kostner B, Magnani F, Marshall JD, Meinzer FC, Phillips N, Ryan MG, Whitehead D (2002b) The relationship between tree height and leaf area: sapwood area ratio. Oecologia 132:12-20. doi:10.1007/s00442-002-0904-x

Meinzer FC, Bond BJ, Karanian JA (2008) Biophysical constraints on leaf expansion in a tall conifer. Tree Physiol 28:197-206

Mencuccini M, Martinez-Vilalta J, Vanderklein D, Hamid HA, Korakaki E, Lee S, Michiels B (2005) Size-mediated ageing reduces vigour in trees. Ecol Lett 8:1183-1190. doi:10.1111/ j.1461-0248.2005.00819.x

Meng SX, Lieffers VJ, Reid DEB, Rudnicki M, Sillins U, Jin M (2006) Reducing stem bending increases the height growth of tall pines. J Exp Bot 57:3175-3182. doi:10.1093/jxb/er1079

Petit G, Anfodillo T, Mencuccini M (2008) Tapering of xylem conduits and hydraulic limitations in sycamore (Acer pseudoplatanus) trees. New Phytol 177:653-664

Phillips N, Bond BJ, Ryan MG (2001) Gas exchange and hydraulic properties in the crowns of two tree species in a Panamanian moist forest. Trees (Berlin) 15:123-130. doi:10.1007/s00468 0000077

Phillips N, Bond BJ, McDowell NG, Ryan MG, Schauer A (2003a) Leaf area compounds height-related hydraulic costs of water transport in Oregon white oak trees. Funct Ecol 17:832-840. doi: 10.1111/j.1365-2435.2003.00791.x

Phillips N, Ryan MG, Bond BJ, McDowell NG, Hinckley TM, Cermak J (2003b) Reliance on stored water increases with tree size in three species in the Pacific Northwest. Tree Physiol 23:237-245

Protz CG, Sillins U, Lieffers VJ (2000) Reduction in branch sapwood hydraulic permeability as a factor limiting survival of lower branches of lodgepole pine. Can J Res 30:1088-1095. doi: $10.1139 /$ cjfr-30-7-1088

Rich PM (1987) Mechanical structure of the stem of arborescent palms. Bot Gaz 148:42-50. doi:10.1086/337626

Rich PM, Helenurm K, Kearns D, Morse SR, Palmer MW, Short L (1986) Height and stem diameter relationships for dicotyledonous trees and arborescent palms of Costa Rican tropical wet forest. Bull Torrey Bot Club 113:241-246. doi:10.2307/2996362
Roupsard O, Bonnefond JM, Irvine M, Berbigier P, Nouvellon Y, Dauzat J, Taga S, Hamel O, Jourdan C, Saint-André L, MialetSerra I, Labouisse JP, Epron D, Joffre R, Braconnier S, Rouzière A, Navarro M, Bouillet JP (2006) Partitioning energy and evapotranspiration above and below a tropical palm canopy. Agric Meteorol 139:252-268. doi:10.1016/j.agrformet.2006.07.006

Ryan MG, Waring RH (1992) Maintenance respiration and stand development in a subalpine lodgepole pine forest. Ecology 73:2100-2108. doi:10.2307/1941458

Ryan MG, Yoder BJ (1997) Hydraulic limits to tree height and tree growth. Bioscience 47:235-242. doi:10.2307/1313077

Ryan MG, Bond BJ, Law BE, Hubbard RM, Woodruff D, Cienciala E, Kucera J (2000) Transpiration and whole-tree conductance in ponderosa pine trees of differing heights. Oecologia 124:553560. doi: $10.1007 / \mathrm{s} 004420000403$

Ryan MG, Phillips N, Bond BJ (2006) The hydraulic limitation hypothesis revisited. Plant Cell Environ 29:367-381. doi: 10.1111/j.1365-3040.2005.01478.x

Schäfer KV, Oren R, Tenhunen JD (2000) The effect of tree height on crown level stomatal conductance. Plant Cell Environ 23:365375. doi:10.1046/j.1365-3040.2000.00553.x

Scholander PF, Hammel HT, Bradstreet ED, Hemmingsen EA (1965) Sap pressure in vascular plants. Science 148:339-346. doi: 10.1126/science.148.3668.339

Sellami MH, Sifaoui MS (2003) Estimating transpiration in an intercropping system: measuring sap flow inside the oasis. Agric Water Manage 59:191-204. doi:10.1016/S0378-3774(02) 00134-8

Sperry JS (1986) Relationship of xylem embolism to xylem pressure potential, stomatal closure, and shoot morphology in the palm Rhapis excelsa. Plant Physiol 80:110-116. doi: $10.1104 / p p .80 .1 .110$

Stiller V, Sperry JS (2002) Cavitation fatigue and its reversal in sunflower (Helianthus annuus L.). J Exp Bot 53:1155-1161. doi: 10.1093/jexbot/53.371.1155

Tomlinson PB (1990) The structural biology of palms. Clarendon Press, Oxford

Uhl NW, Dransfield J (1987) Genera Palmarum. Allen Press, Lawrence

Vanderklein D, Martinez-Vilalta J, Lee S, Mencuccini M (2007) Plant size, not age, regulates growth and gas exchange in grafted Scots pine trees. Tree Physiol 27:71-79

Weitz JS, Ogle K, Horn HS (2006) Ontogenetically stable hydraulic design in woody plants. Funct Ecol 20:191-199. doi:10.1111/ j.1365-2435.2006.01083.x

West GB, Brown JH, Enquist BJ (1999) A general model for the structure and allometry of plant vascular systems. Nature 400:664-667. doi:10.1038/23251

Woodruff DR, Bond BJ, Meinzer FC (2004) Does turgor limit growth in tall trees? Plant Cell Environ 27:229-236. doi:10.1111/ j.1365-3040.2003.01141.x

Woodruff DR, McCulloh KA, Warren JM, Meinzer FC, Lachenbruch B (2007) Impacts of tree height on leaf hydraulic architecture and stomatal control in Douglas-fir. Plant Cell Environ 30:559 569. doi:10.1111/j.1365-3040.2007.01652.x

Yoder BJ, Ryan MG, Waring RH, Schoettle AW, Kaufman MR (1994) Evidence of reduced photosynthetic rates in old trees. For Sci 40:513-527

Zimmermann MH (1973) The monocotyledons: their evolution and comparative biology IV. Transport problems in arborescent monocotyledons. Q Rev Biol 48:314-321. doi:10.1086/407593

Zimmermann MH, McCue KF, Sperry JS (1982) Anatomy of the palm Rhapis excelsa, VIII. Vessel network and vessel-length distribution in the stem. J Arnold Arbor 63:83-95 